\title{
KLAIPĖDOS MOKINIŲ NARKOTIKŲ VARTOJIMAS IR JŲ PRIEINAMUMAS
}

\author{
Sigutė Norkienė, Dalia Jurgaitienė, Vilija Lazarevičiūtė \\ Klaipédos universiteto Sveikatos mokslu fakultetas, Visuomenès sveikatos katedra
}

Raktažodžiai: mokiniai, narkotinių medžiagų vartojimas, narkotikų prieinamumas.

\section{Santrauka}

Tyrimo tikslas - nustatyti narkotikų vartojimą tarp Klaipedos miesto vyresniųjų klasių mokinių ir narkotikų prieinamumą. Tyrimui atlikti pasirinktas kiekybinis apklausos raštu metodas. Tyrime dalyvavo 485 mokiniai iš Klaipedos miesto gimnazijų nuo 16 iki 18 m. amžiaus, iš jų: 209 berniukai ir 276 mergaitès. Statistinè duomenų analizè atlikta naudojant SPSS programos 21.0 versijos paketą.

Rezultatai ir išvados. Dažniausiai mokiniai per paskutinius 12 mèn. ar per paskutines $30 \mathrm{~d}$. vartojo kanapių produktus, be to, vaikinai statistiškai reikšmingai dažniau negu merginos. Ypač dažnai per paskutines 30 d. buvo vartojamas alkoholis ir marihuana tuo pačiu metu. Amfetaminai, ekstazis, kokainas, krekas, LSD ar kitas haliucinogenas, heroinas, haliucinogeniniai grybai buvo vartojami žymiai rečiau. Daugiau nei pusė mokinių turi draugų, kurie marihuaną ar hašišą yra išbandę. Nuo 10 iki 20 proc. mokinių turi draugų, vartojančių LSD ar kitus haliucinogenus, ekstazị, amfetaminus, kokainą kreką, heroiną, haliucinogeninius grybus. Klaipèdos miesto mokinių nuomone, narkotines medžiagas galètų ịsigyti prekiautojo namuose, diskotekoje, bare, gatvejje, parke ir panašaus pobūdžio vietose. Dalis mokinių narkotines medžiagas gali ịsigyti mokykloje. Beveik pusè mokinių nurodè, jog nežino nè vienos vietos, kurioje galètų įsigyti narkotinių medžiagų. Mokiniai, gyvenantys tiek mieste, tiek kaime, nurodè, kad gana lengva ir labai lengva gauti marihuanos ar hašišo. Be to, beveik trečdalio mokinių nuomone, gana lengva nusipirkti LSD ir kitų haliucinogenų, amfetaminų, ekstazio, kokaino, haliucinogeninių grybų. Moksleiviai narkotines medžiagas gauna iš vyresnių draugų, pasidalina grupejje draugų, gauna iš bendraamžių, nusiperka iš draugų, nusiperka iš girdèto žmogaus, kurio asmeniškai nepažista arba nusiperka iš visai nepažįstamo žmogaus.

\section{Ivadas}

Narkotikų vartojimas yra viena pagrindinių Europos jaunų žmonių sveikatos sutrikimų ir mirties priežasčių. Tai liga, kuriai nèra teritorinių, nacionalinių, religinių ribų, kuri nesirenka žmonių pagal amžių, lyți, išsilavinimą ar socialinę padètị [1-4]. Europos narkotikų ir narkomanijos stebėsenos centras (EMCDDA) beveik kasmet pateikia Europos Sajungos šalims tam tikrą analizę narkotikų vartojimo klausimais viename ar kitame kontekste. $2017 \mathrm{~m}$. buvo išversta ị lietuvių kalbą šio centro paruošta analizè: „Europos narkotikų vartojimo paplitimo kaita, tendencijos ir pokyčiai“ [1]. Šioje ataskaitoje daugelis šalių pateikia $2015 \mathrm{~m}$. duomenis, Lietuva pateikia 2012 m. duomenis. Remiantis šia analize, Lietuvos gyventojai daugelį nelegalių narkotikų vartoja mažiau, nei kaimynineje Latvijoje ir mažiau nei Europos Sajungoje. Pvz., amfetaminus nors kartą gyvenime vartojo 1,2 proc. 15-64 m. amžiaus Lietuvos piliečių, MDMA (kitas pavadinimas EKSTAZY) - 1,3 proc., kanapes - 10,5 proc., kokainą - 0,9 proc. Paskaičiavus 15-34 m. amžiaus grupei šie rodikliai yra tik šiek tiek mažesni nei 15-64 m. amžiaus grupei, nors logiškai galvojant turètų būti gerokai didesni, nes išsimeta vyresnio amžiaus žmonių grupe, iš kurių daugelis šiuolaikinių narkotikų net nèra matę. Atskirai 16-18 m. amžiaus mokinių grupei (tokie yra mūsų respondentai) duomenys šioje ataskaitoje nèra pateikiami. Kaip matyti, 2012 m. narkotiką MDMA (ekstazị) vartoja panašus Lietuvos gyventojų skaičius kaip ir amfetaminus. Panašūs duomenys ir apie kokaino, opioidų ir kitų psichiką veikiančių medžiagų vartojimą. Kaip ir ankstesniais laikotarpiais, kanapes vartojančiu asmenų skaičius yra didžiausias: tiek Lietuvoje, tiek kaimyninejje Latvijoje šis rodiklis nors kartą išbandžiusių asmenų 15-64 m. amžiaus grupejje yra apie 10 proc., Europos Sajungoje - 26,3 proc. Tačiau viskas pasikeičia, kai pradedama lyginti duomenis apie mirčių nuo narkotikų skaičių bendrojoje populiacijoje. Lietuvoje šis rodiklis siekia 59 atvejus milijonui 
gyventojų per metus, tai yra 4,2 karto daugiau nei kaimynineje Latvijoje ir 2,7 karto daugiau nei Europos Sajungoje. Tai bylotų, kad Lietuvoje nèra tinkamo šių pacientų gydymo. Tačiau toje pačioje ataskaitoje paanalizavus duomenis apie pirmą kartą besikreipiančius gydytis priklausomus asmenis, toks įspūdis nesusidaro. Pvz., nuo priklausomybės kokainui ir nuo priklausomybės MDMA ar kitoms narkotinėms medžiagoms tiek Lietuvoje, tiek Latvijoje gydytis kreipiasi panašus gyventojų procentas, apskaičiuotas nuo visų priklausomų asmenų skaičiaus. Belieka daryti prielaidą, kad Lietuvoje trūksta kažkokios grandies anksti nustatyti, išaiškinti narkotikų vartotojus ir jiems suteikti pagalbą. Ypač šios spragos aiškiai matomos dèl pagalbos mokiniams, kurie anksti pradeda vartoti narkotikus ir lieka neidentifikuoti. Tai pažymi ir kiti Lietuvos tyrèjai [5-9]. Lietuvoje dèl įvairių priežasčių per mažai daroma apklausų dẻl narkotikų vartojimo moksleiviškame amžiuje arba tos apklausos neatliekamos kiekvienoje mokykloje, tėvai ir visuomenė per vèlai sužino apie savo narkotikus vartojančius vaikus, atitinkamai ir pagalba suteikiama pavèluotai.

Mūsų tyrimas yra bandymas nors dalinai užpildyti šią spragą ir pateikti visuomenei,

1 lentelè. Respondentų atsakymai ị klausimą „Kaip manote, kiek iš Jūsų draugų...“

$P^{*}$ reikšmé - vaikinai statistiškai reikšmingai daugiau turi draugu, vartojančiu narkotikus, negu merginos.

\begin{tabular}{|l|c|c|c|c|c|c|c|}
\hline & Niekas & Keli & Nedaug & $\begin{array}{c}\text { Dauge- } \\
\text { lis }\end{array}$ & Visi & \multirow{2}{*}{ p } \\
\cline { 2 - 7 } & \multicolumn{7}{|c|}{ (absk. sk. ir proc.) } \\
\hline Rūko marihuaną ar hašišą & $212 / 44,1$ & $138 / 28,7$ & $66 / 13,7$ & $54 / 11,2$ & $10 / 2,1$ & $\mathbf{0 , 0 2 2 *}$ \\
\hline $\begin{array}{l}\text { Vartoja LSD ar kitus haliucino- } \\
\text { genus }\end{array}$ & $378 / 79,1$ & $66 / 13,8$ & $17 / 3,6$ & $10 / 2,1$ & $7 / 1,5$ & \multirow{0}{0,021*}{} \\
\hline Vartoja amfetaminą & $412 / 86$ & $39 / 8,1$ & $15 / 3,1$ & $6 / 1,3$ & $7 / 1,5$ & $\mathbf{0 , 0 0 8 *}$ \\
\hline Vartoja heroiną ar kreką & $401 / 83,5$ & $47 / 9,8$ & $16 / 3,3$ & $10 / 2,1$ & $6 / 1,3$ & 0,062 \\
\hline Vartoja ekstazị & $388 / 80,8$ & $48 / 10$ & $27 / 5,6$ & $10 / 2,1$ & $7 / 1,5$ & 0,051 \\
\hline Vartoja heroiną & $437 / 91,2$ & $17 / 3,5$ & $13 / 2,7$ & $5 / 1$ & $7 / 1,5$ & $0,011^{*}$ \\
\hline Vartoja haliucinogeninius grybus & $418 / 87,4$ & $36 / 7,5$ & $9 / 1,9$ & $8 / 1,7$ & $7 / 1,5$ & $\mathbf{0 , 0 2 1 *}$ \\
\hline Vartoja GHB ,gomka“ & $446 / 93,3$ & $14 / 2,9$ & $7 / 1,5$ & $5 / 1$ & $6 / 1,3$ & 0,060 \\
\hline
\end{tabular}

2 lentelè. Respondentų atsakymai ị klausimą „Ar kada nors vartojote bet kurị išvardintą narkotiką?“ p reikšme apskaičiuota, lyginant respondentus pagal lytị.

\begin{tabular}{|c|c|c|c|c|c|c|c|}
\hline & \multicolumn{2}{|c|}{ Berniukai (N/\%) } & \multicolumn{2}{|c|}{ Mergaitės (N/\%) } & \multirow[b]{2}{*}{$\mathrm{x}^{2}$} & \multirow[b]{2}{*}{ lls } & \multirow[b]{2}{*}{$\mathrm{p}$} \\
\hline & $\begin{array}{l}\text { Taip, per } \\
\text { paskutines } \\
30 \text { dienų }\end{array}$ & $\begin{array}{l}\text { Taip, per pa- } \\
\text { skutinius } 12 \\
\text { mèn. }\end{array}$ & $\begin{array}{l}\text { Taip, per } \\
\text { paskutines } \\
30 \text { dienų }\end{array}$ & $\begin{array}{l}\text { Taip, per } \\
\text { paskutinius } \\
12 \text { mėn. }\end{array}$ & & & \\
\hline Amfetaminus & $6 / 2,9$ & $3 / 1,4$ & $4 / 1,5$ & $1 / 0,4$ & 3,429 & 3 & 0,330 \\
\hline $\begin{array}{l}\text { LSD ar bet kurị kitą } \\
\text { haliucinogeną }\end{array}$ & $5 / 2,4$ & $4 / 1,9$ & $2 / 0,7$ & $1 / 0,4$ & 6,124 & 3 & 0,106 \\
\hline Kreką & $5 / 2,4$ & $1 / 0,5$ & $2 / 0,7$ & $1 / 0,4$ & 4,037 & 3 & 0,258 \\
\hline Kokainą & $5 / 2,4$ & $4 / 1,9$ & $3 / 1,1$ & $2 / 0,7$ & 3,227 & 3 & 0,358 \\
\hline Releviną & $5 / 2,4$ & $0 / 0$ & $1 / 0,4$ & $2 / 0,7$ & 5,469 & 2 & 0,065 \\
\hline Heroiną & $5 / 2,4$ & $1 / 0,5$ & $1 / 0,4$ & $0 / 0$ & 5,416 & 3 & 0,144 \\
\hline Ekstazi & $8 / 3,8$ & $5 / 2,4$ & $7 / 2,6$ & $0 / 0$ & 7,417 & 3 & 0,060 \\
\hline $\begin{array}{l}\text { Haliucinogeninius } \\
\text { grybus }\end{array}$ & $4 / 1,9$ & $1 / 0,5$ & $2 / 0,7$ & $1 / 0,4$ & 1,978 & 3 & 0,577 \\
\hline GHB (,gomka“) & $4 / 1,9$ & $1 / 0,5$ & $1 / 0,4$ & $2 / 0,7$ & 2,889 & 2 & 0,236 \\
\hline $\begin{array}{l}\text { Heroiną, „širką" ar } \\
\text { kurị kitą }\end{array}$ & $4 / 1,9$ & $0 / 0$ & $1 / 0,4$ & $2 / 0,7$ & 4,272 & 2 & 0,118 \\
\hline $\begin{array}{l}\text { Alkoholị ir marihu- } \\
\text { aną (hašišą) tuo pačiu } \\
\text { metu }\end{array}$ & $14 / 6,7$ & $13 / 6,3$ & $12 / 4,4$ & $13 / 4,7$ & 2,907 & 3 & 0,406 \\
\hline
\end{tabular}

mokslininkams ir tėvams informaciją, kokia padètis yra Klaipedos mokyklose (gimnazijose) tarp 16-18 m. amžiaus mokinių.

Tyrimo tikslas - nustatyti nelegalių narkotikų vartojimą tarp Klaipedos miesto vyresniujų klasių mokinių ir narkotikų prieinamumą.

Tyrimo medžiaga ir metodai

Tyrimas vyko Klaipėdos miesto mokyklose $2018 \mathrm{~m}$. sausio - kovo ménesiais. Buvo pasirinkta apklausa naudojant anketą, sudarytą pagal tarptautinio ESPAD tyrimo klausimyną. Remiantis Klaipedos miesto savivaldybès duomenimis, 2017-2018 mokslo metais Klaipèdos miesto gimnazijose mokosi 4725 I-IV gimnazijos klasių mokiniai. Pasirinkus 95 proc. reikšmingumo lygmenị ir paklaidos ribą \pm 5 proc., nustatyta, kad norint turèti reprezentatyvią imti, reikia apklausti ne mažiau kaip 355 respondentus. Apklausėme 485 Klaipédos miesto gimnazijų mokinius: iš jų $-43,1$ proc. $(n=209)$ sudarè berniukai ir 56,9 proc. $(\mathrm{n}=276)$ mergaitès. Statistinè duomenų analizè atlikta naudojant SPSS programos paketą (SPSS 21.0). Statistiniam reikšmingumui tikrinti buvo naudojamas chi kvadrato $\left(\chi^{2}\right)$ kriterijus. Parinktas reikšmingumo lygmuo, kai $\mathrm{p}<0,05$.

\section{Tyrimo rezultatai}

Duomenys apie pačių respondentų narkotikų var- 
tojimą pateikti 1 lentelëje. 65,8 proc. vaikinu ir 76,3 proc. merginų teige niekada savo gyvenime nevartoję narkotikų iš kanapių. Likusieji prisipažista išbandę šiuos narkotikus nuo 1 iki 40 kartų. Mokiniai nurodè, kad yra išbandę ir tokius narkotikus kaip amfetaminas, LSD, kokainas, krekas, ekstazis, heroinas, haliucinogeniniai grybai. Nemažai mokinių vartojo alkoholị ir marihuaną (hašišą) tuo pačiu metu. Merginos nelegalius narkotikus vartojo rečiau, tačiau statistiškai reikšmingas skirtumas negautas. 8 mokiniai nurode vartoję ir narkotiką releviną, nors tokio narkotiko nèra, kas verčia abejoti, ar atsakinedami ị klausimus apie savo asmeninę patirtị vartojant narkotikus, mokiniai buvo pakankamai atviri.

2 lenteleje pateikti atsakymai i klausimą „Kaip manote, kiek iš Jūsų draugų vartoja žemiau išvardintus narkotikus?" Iš tyrimo rezultatų matyti, kad mokiniai buvo daug atviresni, kalbėami apie savo draugus. 44,1 proc. mokinių teigè, kad niekas iš jų draugų nėra bandęs marihuanos ar hašišo. Tačiau galime galvoti, kad 55,9 proc. mokinių turi draugų, kurie marihuaną ar hašišą vis dèlto yra išbandę. 28,7 proc. respondentų teigè, kad turi kelis draugus, išbandžiusius šiuos narkotikus, tačiau 13,3 proc. mokinių teigè, kad daugelis ar net visi jų draugai yra išbandę narkotikus iš kanapių. Likusius narkotikus mokinių draugai vartoja žymiai rečiau ir šis procentas svyruoja nuo 6,7 (GHB) iki 20,9 proc. (LSD ir kiti haliucinogenai)

1 paveiksle matyti mokinių atsakymai ị klausimą „Kur galètu įsigyti narkotinių medžiagų?“. Mokiniai ( 24,8 proc.) nurodo, kad narkotiku galètų ịsigyti prekiautojo namuose, diskotekoje, bare ir pan. Panašus skaičius mokinių (27,1 proc.) galètų lengvai nusipirkti narkotiku gatvèje, parke ir panašaus pobūdžio vietose.
Neramina tai, kad 16,8 proc. vaikinų ir 15,3 proc. merginų, (iš viso 15,9 proc.) narkotines medžiagas gali ịsigyti mokykloje. Kitas vietas, kur galima ịsigyti narkotinių medžiagų nurodè 8,7 proc. respondentų. Likusieji 47,6 proc. mokinių nurodė, jog nežino nei vienos vietos, kuriose galètų įsigyti narkotinių medžiagų.

Kad neįmanoma ịsigyti vienų ar kitų narkotinių medžiagų nurodè nuo 1,2 iki 4,8 proc. mieste gyvenančių mokinių ir nuo 2,5 iki 8,9 proc. kaime gyvenančių mokinių. Kad gana lengva ir labai lengva gauti marihuanos ar hašišo nurodè 63,9 proc. miesto gyventojų ir 62 proc. kaimo gyventojų. Be to, mokinių nuomone, gana lengva nusipirkti LSD ir kitų haliucinogenų ( 29 proc.), amfetaminų (19,5 proc.), ekstazio (29,1 proc.), kokaino (23,7 proc.), kreko (13,1 proc.), haliucinogeniniu grybų (20,5 proc.). Kaimo mokiniams ịsigyti narkotikus būtų šiek tiek sunkiau, bet įmanoma. Šie duomenys atskirai lentelèse nepateikiami.

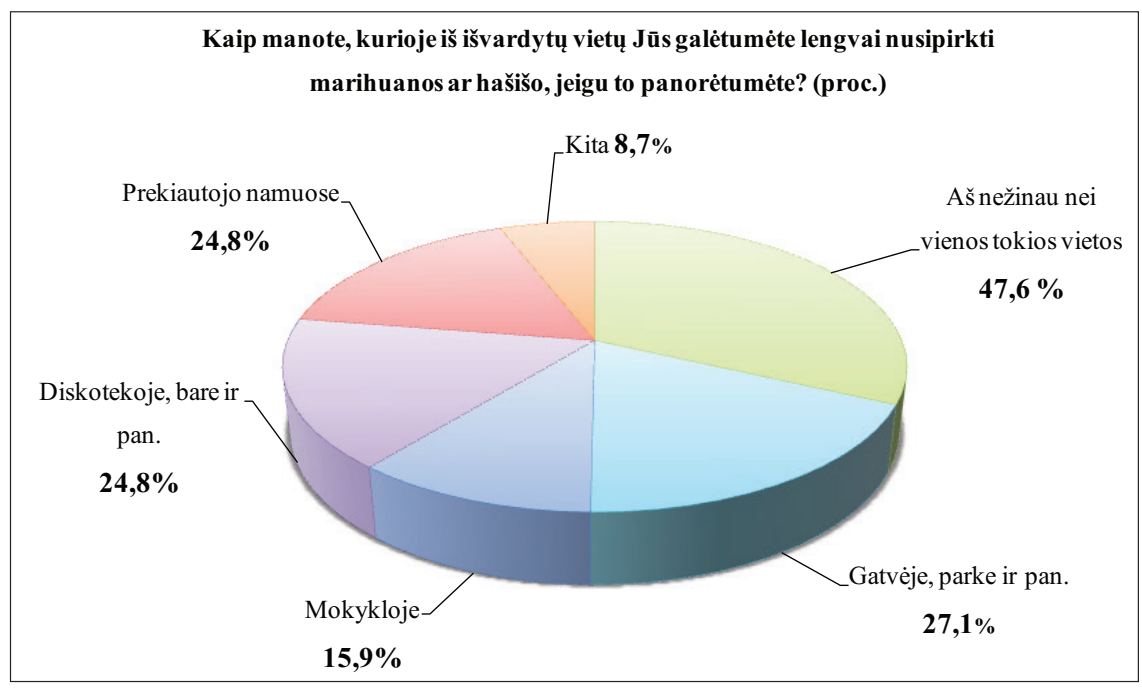

1 pav. Respondentų atsakymai ị klausimą „Kaip manote, kurioje iš išvardytų vietų Jūs galètumète lengvai nusipirkti marihuanos ar hašišo, jeigu to panorètumète?"

3 lentelė. Respondentų atsakymai ị klausimą „Kaip gavote šių narkotinių medžiagų? p reikšme apskaičiuota, lyginant respondentus pagal lyti.

\begin{tabular}{|c|c|c|c|c|c|}
\hline & \multicolumn{2}{|c|}{ Berniukai (N/\%) } & \multicolumn{2}{|c|}{ Mergaitès (N/\%) } & \multirow{2}{*}{$\mathrm{p}$} \\
\hline & Taip & $\mathrm{Ne}$ & Taip & $\mathrm{Ne}$ & \\
\hline Davè vyresnis brolis ar sesuo & $1 / 0,5$ & $206 / 99,5$ & $2 / 0,7$ & $273 / 99,3$ & 0,736 \\
\hline Davè vyresnis $(\dot{\mathrm{e}})$ draugas $(\dot{\mathrm{e}})$ & $17 / 8,2$ & $190 / 91,8$ & $18 / 6,5$ & $257 / 93,5$ & 0,485 \\
\hline 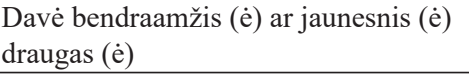 & $6 / 2,9$ & $201 / 97,1$ & $12 / 4,4$ & $263 / 95,6$ & 0,401 \\
\hline $\begin{array}{l}\text { Davė girdètas žmogus, kurio aš } \\
\text { asmeniškai nepažįstu }\end{array}$ & $6 / 2,9$ & $201 / 91,1$ & $5 / 1,8$ & $270 / 98,2$ & 0,432 \\
\hline Davė nepažịstamas žmogus & $3 / 1,4$ & $204 / 98,6$ & $1 / 0,4$ & $274 / 99,6$ & 0,193 \\
\hline Pasidalijome grupè draugų (ių) & $15 / 7,2$ & $192 / 92,8$ & $21 / 7,6$ & $254 / 92,4$ & 0,872 \\
\hline Nusipirkau iš draugo (ès) & $7 / 3,4$ & $200 / 96,6$ & $6 / 2,2$ & $269 / 97,8$ & 0,421 \\
\hline $\begin{array}{l}\text { Nusipirkau iš girdèto žmogaus, kurio } \\
\text { asmeniškai nepažįstu }\end{array}$ & $9 / 4,3$ & $198 / 95,7$ & $5 / 1,8$ & $270 / 98,2$ & 0,102 \\
\hline Nusipirkau iš nepažįstamo & $5 / 2,4$ & $202 / 97,6$ & $7 / 2,5$ & $268 / 97,5$ & 0,928 \\
\hline Man davė vienas iš mano tėvų & $9 / 4,3$ & $198 / 95,7$ & $14 / 5,1$ & $261 / 94,9$ & 0,705 \\
\hline Paėmiau tai namuose, be tėvų leidimo & $0 / 0$ & $207 / 100$ & $5 / 1,8$ & $270 / 98,2$ & 0,051 \\
\hline Kita & $8 / 3,9$ & $199 / 96,1$ & $11 / 4$ & 264,96 & 0,940 \\
\hline
\end{tabular}


Iš 3 lentelès matyti, kad narkotikus mokiniai dažniausiai gavo iš vyresnių draugų (14,7 proc.) arba pasidalijo grupejje draugų (14,8 proc.). Vaikinams dažniausiai davė vyresnis draugas (è) $-8,2$ proc., tuo tarpu merginos nurode, kad narkotines medžiagas pasidalijo grupeje draugų $-7,6$ proc. Buvo 4,3 proc. vaikinu ir 5,1 proc. merginų, kurie teigè, kad narkotines medžiagas jiems davè vienas iš tèvų, bet, mūsų nuomone, tai buvo migdomieji ar raminamieji vaistai. 2,9 proc. vaikinų ir 4,4 proc. merginų narkotikus davè bendraamžis ar jaunesnis draugas. 3,5 proc. vaikinų ir 2,2 proc. merginų nurodè, kad narkotines medžiagas jie nusipirko iš draugo(ès). Iš girdèto žmogaus, kurio asmeniškai nepažįsta, narkotikus įsigijo 2,9 proc. vaikinų ir 1,8 proc. merginų. Iš visai nepažįstamo žmogaus narkotikus nusipirko 6,7 proc. vaikinų ir 4,3 proc. merginų.

\section{Rezultatų aptarimas}

Lietuvoje atliekamų panašių tyrimų rezultatus palyginti sunku, nes skiriasi tyrimų metodikos, demografinès charakteristikos, respondentų amžius. Galima palyginti tik bendras tendencijas, kurios dažnai sutampa. Mūsų atlikto tyrimo rezultatai parodè, kad daugiausia respondentų per paskutinius 12 mèn. (21,8 proc.) ir per paskutines $30 \mathrm{~d}$. (12,4 proc.) vartojo narkotikus iš kanapių. Lyginant pagal lytị narkotikus statistiškai reikšmingai dažniau vartojo vaikinai negu merginos. Per paskutines $30 \mathrm{~d}$. dažnai buvo vartojamas alkoholis ir marihuana tuo pačiu metu (5,4 proc.), amfetaminai, ekstazis ir kokainas - nuo 2 iki 4 proc., o LSD ar bet kuris kitas haliucinogenas, krekas, heroinas ir haliucinogeniniai grybai - apie 2 proc., GHB ,gomka“ - apie 1 proc. Kadangi mūsų tirtų mokinių kontingentas nuo ESPAD $2015 \mathrm{~m}$. tyrime dalyvavusių respondentų skiriasi pagal amžių (mūsų respondentai buvo 16-18 m. amžiaus) lyginti su šio tyrimo duomenimis galime tik iš dalies.

ESPAD $2015 \mathrm{~m}$. tyrimo duomenimis [10], Lietuvoje nelegalių narkotikų vartojimas tarp 15-16 m. mokinių per pastaruosius ketverius metus sumažejo beveik 3 procentais. 2015 m. bent vieną - du kartus gyvenime vartojusių koki nors narkotiką paauglių buvo 19,2 proc. (2011 m. 21,9 proc.). Europoje bendras neteisètų narkotinių medžiagų vartojimas išlieka stabilus ir nedidèja šioje amžiaus grupejje, tačiau išlieka gana aukštas (18 proc.). Rezultatai skiriasi kiekvienoje valstybeje ir svyruoja nuo 6 proc. iki 37 proc. Lietuvoje, kaip ir Europoje, populiariausiu nelegaliu narkotiku išlieka kanapès. 17,7 proc. apklaustujų nurodè, kad nors kartą gyvenime vartojo kanapes (2011 m. - 19,6 proc.) [10,11].

ESPAD 2015 tyrimą pristatę mokslininkai perspejjo apie naujas grèsmes, su kuriomis susiduria Europos paaugliai. 1-10 proc. paaugliu (Europos vidurkis 4 proc., Lietuvoje $-5,4$ proc.) teige, kad nors kartą gyvenime vartojo naujas psichoaktyvias medžiagas (NPS), o 3 proc. Europos paauglių teigè, kad jie šias medžiagas vartojo per pastaruosius metus. NPS tarp paauglių tapo populiaresnėmis medžiagomis negu amfetaminas, ekstazis, kokainas ar LSD [10].

Kadangi tyrimą vykdeme naudodamiesi ESPAD $2003 \mathrm{~m}$. anketa, joje kol kas nebuvo klausimų apie naujas psichoaktyvias medžiagas. Ateityje tokius klausimus būtina ịtraukti.

Klaipėdos miesto mokinių nuomone ( 24,8 proc.), narkotines medžiagas jie galètų ịsigyti prekiautojo namuose, diskotekoje, bare ar panašiose vietose. 27,1 proc. respondentų galètų lengvai nusipirkti narkotikų gatvejje, parke ir kitose panašaus pobūdžio vietose. Be to, 15,9 proc. mokinių narkotines medžiagas galètų ịsigyti mokykloje. Kitas vietas, kur galima įsigyti narkotinių medžiagų, nurodè 8,7 proc. respondentų. V. Andrejevo (2015) straipsnyje [12] analizuojama Kauno miesto situacija (kuri, be abejonès, panaši ir ị kitų didžiujų miestų situaciją) šiuo klausimu. Straipsnyje pateikiama informacija (iš respondentų atsakymų) apie narkotikų ịsigijimo galimybes bei jų rūšis konkrečiose Kauno vietose. Iš tyrimo rezultatų matyti, kad ypač lengva Kaune įsigyti kanapių, nors ir kiti nelegalūs narkotikai yra prieinami. Dažniausiai paminèta vieta, kur būtu galima lengvai nusipirkti marihuanos arbo hašišo, yra prekiautojo namai, antroje vietoje - naktiniai klubai, barai, diskotekos, trečioje vietoje - gatvè, parkas. Tai visiškai sutampa su mūsų tyrimo rezultatais. Jau 2005 m. 9,2 proc. Lietuvos gyventojų (2005 m. RAIT tyrimo duomenimis ) sakè, kad žino, kur issigyti nelegalių narkotikų [13].

Klaipèdos mokiniai nurode, kad narkotines medžiagas dažniausiai gauna iš vyresnių draugų - 14,7 proc., pasidalina grupejje draugų - 14,8 proc., nusiperka iš girdèto žmogaus, kurio asmeniškai nepažįsta $-6,2$ proc., nusiperka iš draugo (ès) - 5,6 proc., nusiperka iš nepažįstamo žmogaus $-4,9$ proc. Šie mūsų duomenys panašūs ị ESPAD $2011 \mathrm{~m}$. ir ESPAD $2015 \mathrm{~m}$. tyrimų rezultatus [10,11] ir Lietuvoje atliktų tyrimų rezultatus [13].

Mūsų tyrimo rezultatai parodè, kad respondentai buvo daug atviresni kalbėdami apie savo draugus, negu apie save. 44,1 proc. mokinių teigè, kad niekas iš jų draugų nèra bandęs marihuanos ar hašišo. Tačiau galime galvoti, kad 55,9 proc. moksleivių turi draugų, kurie marihuaną ar hašišą vis dèl to yra išbandę. 28,7 proc. moksleivių teigè, kad turi kelis draugus, išbandžiusius šiuos narkotikus, o 13,7 proc. teigè, kad tik nedaug jų draugų išbandẻ kanapių produktus. Mažiau nei 10 proc. respondentų teigé, kad turi draugų, vartojančių heroiną, o nuo 10 iki 20 proc. mokinių turi draugų, vartojančių ekstazị, amfetaminus, kokainą, kreką ir haliucinogeninius grybus. Apie 20 proc. ar net daugiau mokinių turi draugų, kurie vartoja LSD ar kitus haliucinogenus. Panašius rezultatus 2015 metais gavo 
D. Miniauskienè, tirdama Šiaulių miesto mokinius [14].

Lietuvoje narkotikų, tabako ir alkoholio kontrolès departamento atliekami tyrimai [13], tarptautiniai moksleiviu sveikatos ir gyvensenos tyrimai: „Alkoholio ir kitų narkotikų tyrimai Europos mokyklose - ESPAD“ [10], ,Tarptautinis moksleiviu sveikatos ir gyvensenos tyrimas - HBSC" [15] ir kiti rodo, kad psichoaktyvių medžiagų - alkoholio, tabako, narkotikų vartojimo problema tarp Lietuvos paauglių yra labai aktuali.

\section{Išvados}

1. Atlikto tyrimo rezultatai parodè, kad dažniausiai mokiniai per paskutinius 12 mèn. ar per paskutines $30 \mathrm{~d}$. vartojo kanapių produktus, be to, vaikinai statistiškai reikšmingai dažniau negu merginos. Ypač dažnai per paskutines $30 \mathrm{~d}$. buvo vartojamas alkoholis ir marihuana tuo pačiu metu. Amfetaminai, ekstazis, kokainas, krekas, LSD ar kitas haliucinogenas, heroinas, haliucinogeniniai grybai buvo vartojami žymiai rečiau.

2. Tyrimo rezultatai parodè, kad respondentai buvo daug atviresni kalbėdami apie savo draugus, negu apie save. Didesnė dalis moksleivių turi draugų, kurie marihuaną ar hašišą yra išbandę. Apie trečdalis mokinių teigè, kad turi tik kelis draugus, išbandžiusius šiuos narkotikus, o apie dešimtadalis teigè, kad daugelis ar net visi jų draugai yra išbandę kanapių produktus. Nuo 10 iki 20 proc. mokinių turi draugų, vartojančių LSD ar kitus haliucinogenus, ekstazį, amfetaminus, kokainą kreką, heroiną, haliucinogeninius grybus.

3. Klaipedos miesto mokinių nuomone, narkotines medžiagas galètų i̇sigyti prekiautojo namuose, diskotekoje, bare, gatvejje, parke ar panašaus pobūdžio vietose. Dalis mokiniu narkotines medžiagas gali įsigyti mokykloje. Beveik pusė mokinių nurodè, jog nežino nei vienos vietos, kuriose galètų ịsigyti narkotinių medžiagų.

4. Mokiniai, gyvenantys tiek mieste, tiek kaime, nurode, kad gana lengva ir labai lengva gauti marihuanos ar hašišo. Be to, beveik trečdalio mokinių nuomone, gana lengva nusipirkti LSD ir kitų haliucinogenų, amfetaminų, ekstazio, kokaino, haliucinogeninių grybų. Kaimo gyventojams ịsigyti narkotikus būtų šiek tiek sunkiau, bet įmanoma.

5. Moksleiviai narkotines medžiagas gauna iš vyresnių draugų, pasidalina grupèje draugų, gauna iš bendraamžių, nusiperka iš draugų, nusiperka iš girdèto žmogaus, kurio asmeniškai nepažįsta arba nusiperka iš visai nepažįstamo žmogaus.

\section{Literatūra}

1. Europos narkotiku vartojimo paplitimo kaita. Tendencijos ir pokyčiai. Europos narkotikų ir narkomanijos stebėsenos centras, 2017; 50-72.
2. Europeon Monitoring Centre for Drugs and Drug Addiction. European Drug Report. Lisbon: EMCDDA, 2017; 19-23.

3. Wurcel A, Merchant E, Clark R, Stone D. Emerging and underrecognized complications of illicit drug use. Clinical Infectious Diseases: an official publication of the infectious diseases society of America, 2015; 61(12):1840-9.

https://doi.org/10.1093/cid/civ689

4. Ignatavičiūtè L. 2012-2016 statistinių duomenų apie psichikos ir elgesio sutrikimus, vartojant psichiką veikiančias medžiagas, apžvalga. Valstybinis psichikos sveikatos centras, Vilnius, 2016. [žiūrèta $2018 \mathrm{~m}$. sausio 23d.]. Prieiga per internetą: http:// www.vpsc.1t/images/stories/2017/PA_2012_2016.pdf

5. Bankauskienė I. Vyresniųjų klasių mokinių žinių, gyvenimo igūdžiu įsivertinimas ir nuomonẻ apie psichoaktyviųu medžiagų vartojimo prevenciją mokykloje. Visuomenès sveikata, 2013; 2(61): 72-81.

6. Čaplinskas S. Lietuvos moksleivių psichotropinių medžiagu (narkotikų) vartojimo, pasekmių ir priežastinių ryšių tyrimas. Sveikatos mokslai, 2013; 23(2): 43-48.

7. Jurgaitienè D. Narkotikų vartojimo paplitimas tarp moksleivių ir lemiantys veiksniai. Monografija. Klaipèda, S. Jokužio leidykla-spaustuvè, 2010; 1-250.

8. Apklausos apie psichoaktyviụjų medžiagų vartojimo aplinkos prevencijos strategijų taikymą Lietuvos bendrojo ugdymo mokyklose rezultatų ataskaita. Narkotikų, tabako ir alkoholio kontrolès departamentas, Vilnius, 2014.

9. Gintalaitė D., Vaitkevičius R., Pilkauskienė I. Paaugliu alkoholio ir kitų narkotikų vartojimo rizikingumo ir asmens, bendraamžių bei šeimos lygmens rizikos ir apsauginių veiksnių ryšys, remiantis socialinio vystymosi modeliu. Visuomenès sveikata, 2013; 1(60):30-41.

10. ESPAD Report 2015. Rezults from the European school survey project on alcohol and other drugs. The ESPAD group, Luxembourg, 2015; 39-87.

11. Allaste A. A, Arpa S, Bellis M, Chileva A. The 2011 ESPAD report. Sweden, Stockholm, 2012; 10-13.

12. Andrejevas V. Studentų nuomoné apie nelegalių narkotikų prieinamumą Kauno mieste. Visuomenės saugumas ir viešoji tvarka, 2015; 13:4-10.

13. Narkotikų vartojimas ir jų padariniai. Narkotikų, tabako ir alkoholio departamentas. Vilnius, 2016.

14. Miniauskienè D. Moksleivių psichoaktyvių medžiagų vartojimo vertinimas. Biomedicinos mokslų daktaro disertacija, Kaunas, 2015.

15. Zaborskis A, Šmigelskas K, Vaičiūnas T, Veryga A, Žemaitiené N, Mocevičienè R. Lietuvos mokinių gyvensena. $2014 \mathrm{~m}$. HBSC tyrimas, 2016; 1-54.

\section{DRUG CONSUMPTION AMONG SCHOOLCHILDREN} S.Norkienė, D.Jurgaitienė, V.Lazarevičiūtė

Key words: schoolchildren, illegal drugs, the use of drugs, drug availability. 
Summary

The purpose of the study - to clarify the drug use among Klaipeda pupils, the availability of drugs and the reasons for their use. The quantitative survey written method was chosen for the research. The survey involved 485 respondents from several Klaipeda city gymnasiums: 209 boys and 276 girls, $16-18$ years old. The statistical analysis of data is performed using SPSS software package (SPSS 21.0). The significance level has been selected, when $\mathrm{p}<0,05$.

Results and conclusions. Usually, pupils in the last 12 months or last 30 days used cannabis products; in addition, boys are statistically significantly more use of cannabis products than girls. Especially often during the last 30 days have been used alcohol and marijuana at the same time. Amphetamines, ecstasy, cocaine, crack, LSD or other hallucinogen, heroin, hallucinogenic mushrooms have been used much less frequently. More than half of the students have friends who have tried marijuana or hashish. From 10 to 20 percent pupils have friends who use LSD or other hallucinogens, ecstasy, amphetamines, cocaine crack, heroin, hallucinoge- nic mushrooms. According to pupils of Klaipeda city, drugs could be purchased at the merchant's home, at a discotheque, in bars, on the street, in a park and in similar places. Some pupils can buy narcotic drugs at school. Almost half of the pupils indicated that they were not aware of any place where they could buy narcotic drugs. Pupils living both in the city and in the countryside said that it is relatively easy and very easy to get marijuana or hashish. In addition, almost one third of pupils consider it fairly easy to buy LSD and other hallucinogens, amphetamines, ecstasy, cocaine, and hallucinogenic mushrooms. Pupils receive drugs from older friends, share in a group of friends, get their peers, buy from friends, and buy from a guy who is not personally known or bought from a stranger.

Correspondence to: v.lazareviciute@gmail.com

Gauta 2018-11-26 